\title{
Cardiac echocardiogram findings of severe acute respiratory syndrome coronavirus-2-associated multi-system inflammatory syndrome in children - CORRIGENDUM
}

\section{Corrigendum}

Cite this article: Harahsheh AS, Krishnan A, DeBiasi RL, Olivieri LJ, Spurney C, Donofrio MT, Cross RR, Sharron MP, Frank LH, Berul Cl, Christopher A, Dham N, Srinivasalu H, Ronis T, Smith KL, Kline JN, Parikh K, Wessel D, Bost JE, Litt S, Austin A, Zhang J, and Sable CA (2022) Cardiac echocardiogram findings of severe acute respiratory syndrome coronavirus-2associated multi-system inflammatory syndrome in children - CORRIGENDUM. Cardiology in the Young 32: 727. doi: 10.1017/ S1047951121003735

First published online: 31 August 2021

\section{Ashraf S. Harahsheh, Anita Krishnan, Roberta L. DeBiasi, Laura J. Olivieri,} Christopher Spurney, Mary T. Donofrio, Russell R. Cross, Matthew P. Sharron, Lowell H. Frank, Charles I. Berul, Adam Christopher, Niti Dham, Hemalatha Srinivasalu, Tova Ronis, Karen L. Smith, Jaclyn N. Kline, Kavita Parikh, David Wessel, James E. Bost, Sarah Litt, Ashley Austin, Jing Zhang and

\section{Craig A. Sable}

DOI: https://doi.org/10.1017/S1047951121003024 Published online by Cambridge University Press: 08 July 2020

The authors apologise that upon publication of this article the affiliation department information for author James E. Bost was incorrect.

The full affiliation for the author is:

Division of Biostatistics and Study Methodology, Children's National Hospital, Washington, DC, USA

The online version of this article has been updated.

\section{Reference}

Harahsheh, A., Krishnan, A., DeBiasi, R., Olivieri, L., Spurney, C., Donofrio, M., .. Sable, C. (2021). Cardiac echocardiogram findings of severe acute respiratory syndrome coronavirus-2-associated multi-system inflammatory syndrome in children. Cardiology in the Young, 1-9. doi: 10.1017/S1047951121003024 